\title{
Interest Rate - Private Capital Formation Nexus in South Africa: Bounds Test Approach
}

\author{
John Khumalo \\ University of South Africa (UNISA) \\ P.O. Box 392, Pretoria, 0003 \\ khumamj@unisa.ac.za
}

Doi:10.5901/mjss.2014.v5n1p181

\begin{abstract}
The study uses the annual time series data for the period 1975 - 2012 to empirically examine the impact of monetary policy on private capital formation in South Africa with the view to establish any long-run relationship. The unit root test was conducted prior to regression using the Dickey-Fuller Generalised Least Squares (DF-GLS) and the $\mathrm{Ng}-$ Perron tests. The Granger causality test was also conducted to establish the direction of causation between variables included in the model. The unit root test results reveal that inflation, gross private capital formation and real exchange rate are stationary at first difference while real interest rate is stationary at levels. The bounds test approach asserts that variables could still drift together even when they are integrated of different orders (Pesaran, 2001). Cointegration test indicates an existence of long-run relationship among the variables included using Autoregressive Distributed Lag(ARDL)-ECM cointegration procedure advanced by Pesaran et al.(2001). The results of this study indicate that the cost of capital (interest rate) exerts a significant and negative impact on South Africa's private capital formation.
\end{abstract}

Keywords: Private capital formation, Interest rates, monetary policy, Bounds test, Cointegration,

\section{Introduction}

The role of macroeconomic policies on private capital formation has drawn interests amongst researchers and analysts. The private sector is seen as the main engine forengineering economic growth and development since the public institutions are considered to be inefficient, thus a need for promoting private capital formation. The financial performance of public enterprises has always been disappointing despite the huge financial resources dispersed to them. The tendency to heighten private sector participation has prominently shaped policy advice at regional and international financial institutions and policy making particularly in developing countries, giving rise to a wave of privatization programmes, liberalization policies and other policies geared towards the private sector development (Badawi, 2005).

Okoliet al (2007) in trying to find if macroeconomic policies had an impact of private capital formation did in fact find that such policies play a cruacial role. Conversely, Chhiber and Wijnbergen (1988), and Rossiter (2002) report negative effect of public investment on private investment. They argue that public investment may crowd out private investment if the additional investment is financed by a deficit, which leads to an increase in the interest rates, credit rationing and tax burden. As relates to the private capital formation impact of monetary policy, similar imprecision still holds. The advocates of the classical paradigm still argue that money supply, hence monetary policy variables have little or no influence on real economic outcomes, either in the short-run or long-run, that's monetary policy is window dressing (Tobin andBuiter, 1980).

In their paper, Slater and Anthony (2003), support the classical proposition that money is window dressing in both short run and long-run. In other words monetary policy variables were less effective determinants of private capital formation. However, their study was carried out for developed nations. In such circumstances, caution must be exercised not to generalize such conclusions for developing countries (LDCs). Contrary, to the above conclusion, Badawi (2005) argues that monetary policy through credit and interest rate channels has significant impact on private capital formation.Badawi (2005) found these variables to have had significant impact on private capital formation in Sudan over the period 1969-1998. Indeed his findings support the modern Keynesian Paradigm.

Perhaps the primary reason for the low level of private investment in Sub-Saharan Africa is the perception, held by both domestic and foreign investors, that the risk-adjusted rate of return on capital is low. In literature, three major sources of risk appear to be particularly relevant: macroeconomic instability; inadequate legal systems-in particular, the difficulty of enforcing contracts; and political risk. With particular relevance to developing countries, Barrow (1997), show 
that broad number of factors determine private capital formation in developing countries, particularly the most relevant are output growth, FDI, real exchange rates, fiscal policy in the form of government spending (fiscal deficits), real interest rates and uncertainty. However, the potential impacts of fiscal and monetary austerities on the private sector's ability to commit substantial capital outlays and various institutions to mobilize required savings have not been fully ascertained. South Africa, despite its notable fiscal and monetary policy prudence and improvements in economic performance, is still confronted with a number of constraints such as low levels of savings and investment to allow for sustained growth. See figure 1 below.

Figure 1: GPCF and GGCF trends

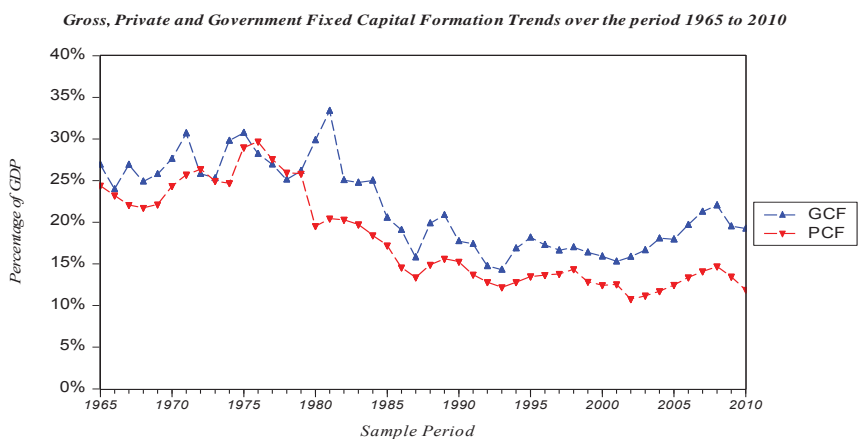

The ratio of PCF to GDP has declined from 29.7\% in 1976 to 10.8\% in 2002. From 2008, it showed a slight increase of about 4\%, but since then it has shown some decline again. On the other hand GCF has seen the same pattern, except in 1981 where GCF increased to $33.38 \%$. There is therefore a need to empirically test the impact of the various macroeconomic policies ${ }^{1}$, available in South Africa on private sector development. That is on private sector capital formation in the economy.

\section{Review of Literature}

A number of studies have attempted to assess empirically the link between macroeconomic policies and private capital formation in both developed and developing countries. Although, the empirical results vary from one study to another, in other cases general conclusions are drawn. The relationship between monetary policy and private capital formation could be traced back to Schumpeter's theory of development in 1934, as well as Keynes (1936). Both these authors argue for the role of credit in the development process. In general, there are basically three channels through which, Monetary Policy could affect private capital formation: the credit channel, interest rate channel, and money supply channel.

Concerning the role of money in physical capital accumulation, two conflicting hypotheses have emerged in literature. The substitutability hypothesis articulated in the works of Tobin (1965) and Johnson (1967), view money as a substitute for physical assets. Thus an increase in the rate of an interest on monetary asset would result in a portfolio shift towards such assets and the result would be a reduced rate of physical capital accumulation and growth. The complimentarity hypothesis originated from the more recent works of McKinnon (1973) and Shaw (1973) and was formalized by Galbis (1979) and Fry (1980). According to McKinnon, in most developing countries, private investment relies on self-financing because of the rudimentary and fragmented nature of capital markets in these countries. Given the lumpiness of investment projects, the requirement that the investor first accumulates the money balances needed to finance or acquire physical capital is enhanced. In this context, a higher real rate of return on money balances is likely to raise investment income ratio, because it enables would-be investors to accumulate equity faster and also because this equity makes them more eligible for any limited institutional financing that may be available.

The debt-intermediation view of Shaw also focuses on this capacity of deposit accumulation to enhance the flow of deposit into banks. Thus, the emphasis in both the complimentarity and debt-intermediation hypotheses is in the use of high interest rates to enhance investment project financing either through own funds or in part through credit borrowing. Emerging, from McKinnon and Shaw hypothesis therefore, neither low interest rates nor any credit allocation policy that

${ }^{1}$ The macroeconomic policies are limited to monetary and exchange rate policies only 
is unduly influenced will enhance private capital accumulation.

In regard to private capital formation influence of monetary policy, several empirical studies as already mentioned, proxied such an influence through the credit channel and interest rate channel. For instance, Matin and Wasow (1992) conducted a study to test the impact of adjustment policies in Kenya during 1968-88, the results of this study demonstrated that restrictive monetary policy in the form of credit control to the provide sector had debilitating effect on private capital formation. The flow of credit to the private sector was found significant at 1 percent level of significance and real interest rates variable was found significant at 5 percent level with an expected negative sign. These results were reinforcing those attained by Shafik (1992) for Egypt, Ogunbenroet al (1996) in a study done for Nigeria between 1983-1996 and Oshikoya (1992) in a study done for Kenya. A similar conclusion that domestic credit and real interest rates matter for private capital formation was reached by Kumar and Mlambo (1995) in a study conducted for SubSaharan Africa, using a pooled time series and cross sectional data for the period 1970-1993. These authors experimented with both linear and log linear models and interpreted the results from log-linear, which was considered more appropriate.

In light of these problems, several authors including Belloc and Vertova (2004), Badawi (2003), Mittnik and Neumann (2001), Ligthart (2000), and Ghali (1998), recommend that such dynamic equations be specified and estimated as vector autogressive (VAR) Model, in order to account for the aforementioned problems and spurious correlations in the regression. Furthermore, to account for the delayed response with the parsimonious lag structure, due to the fact that private investment takes time to respond to changes in policy variables. Badawi (2005), in particular, utilized VAR model to investigate the impact of both fiscal and monetary policies on private capital formation in Sudan over the period 196998. In order to distinguish precisely between the short-run and long-run impacts, he proceeded to use the Vector Error Correction Model (VECM) embodied in the VAR technique. In his study, the VAR and VECM models employed were specified as:

$$
Z_{t}=A_{0} D_{t}+A_{1} Z_{t-1}+A_{2} Z_{t-2}+\ldots \ldots \ldots \ldots \ldots+\ldots+A_{k} Z_{t-k}+\varepsilon_{t}
$$

where $Z_{t=n \times 1}$ vector containing $n$ endogenous variables in the system, which were Private Investment (I), real output (Y), public sector investment (PSI), real exchange rate (RE), and real credit to the private firms (CR); (all variables in natural logarithm). $\mathrm{D}=$ a vector holding deterministic terms, and $\varepsilon_{t}=$ nxn dimensional vector of multivariate random error terms with mean and covariance matrix given by $\Sigma$. The Error Correction representation of the above VAR took the following form:

$$
\Delta \mathbf{Z}_{\mathrm{t}}=\psi \mathrm{D}_{\mathrm{t}}+\Pi \mathrm{Z}_{\mathrm{t}-1}+\Gamma_{1} \Delta \mathrm{Z}_{\mathrm{t}-1}+\Gamma_{2} \Delta \mathrm{Z}_{\mathrm{t}-2}+\ldots \ldots \ldots+\ldots+\Gamma_{\mathrm{k}-1} \Delta \mathrm{Z}_{\mathrm{t}-\mathrm{k}+1}+\mathrm{V}_{\mathrm{t}}
$$

where $\Pi=$ long-run matrix containing two matrices, $\alpha$ and $\beta$ holding long-run adjustment coefficients and long-run elasticities respectively. Accordingly, the current study employs the Bounds test approach to study the impact of monetary policies on private capital formation in South Africa.

\section{Econometric Specification of the Model and Results}

The abovementioned model specification has been extended and modified in order to derive a model that is deemed appropriate for evaluating the impact of fiscal and monetary policies on private capital formation in South Africa. The general dynamic form of the econometric model used in this study is:

$$
G P C F_{\mathrm{t}}=\beta_{0}+\sum_{\mathrm{i}=1}^{\mathrm{k}} \beta_{1 \mathrm{i}} G P C F_{\mathrm{t}-\mathrm{i}}+\sum_{\mathrm{i}=0}^{\mathrm{k}} \beta_{\mathrm{ti}} Y_{\mathrm{t}-\mathrm{i}}+\delta_{0} D_{\mathrm{t}}+\mathbf{v}_{\mathrm{t}}
$$

where, $\mathrm{GPCF}_{\mathrm{t}}=$ gross private investment, $\mathrm{Y}_{\mathrm{t}-\mathrm{i}}$ represents a set of all explanatory variables to be included in the model and their lags, $D_{t}$ represents a set of deterministic terms (dummies, trends and others). $V_{t}$ is a well behaved error term. Therefore, specifying equation (3) as a VAR system of equations gives equation (4), which is compactly written as equation (5):

$$
\begin{aligned}
& Y_{\mathrm{t}}=\boldsymbol{\delta}_{0} D_{\mathrm{t}}+\boldsymbol{\delta}_{1} Y_{\mathrm{t}-1}+\boldsymbol{\delta}_{2} Y_{\mathrm{t}-2}+\ldots \ldots \ldots \ldots \ldots+\boldsymbol{\delta}_{\mathrm{k}} Y_{\mathrm{t}-\mathrm{k}}+\boldsymbol{\pi}_{\mathbf{t}} \\
& Y_{\mathbf{t}}=\boldsymbol{\delta}_{0} D_{\mathbf{t}}+\sum_{\mathrm{i}=1}^{\mathbf{k}} \boldsymbol{\delta}_{\mathrm{i}} Y_{\mathrm{t}-\mathrm{i}}+\boldsymbol{\pi}_{\mathrm{t}}
\end{aligned}
$$

\section{Research Findings}




\subsection{Granger causality analysis}

The results of causality test are reported in table 1 below. We conclude that there is unidirectional causality with causality running from consumer confidence to consumer spending. The study excluded other explanatory variables such as personal tax, inflation and unemployment after the preliminary tests showed that these variables were not statistically significant in explaining consumer spending. As much as other studies could come to a different conclusion about the dropping of these variables, they are found to be insignificant for South Africa.

Table 1: VAR Granger Causality/Block Exogeneity Test results

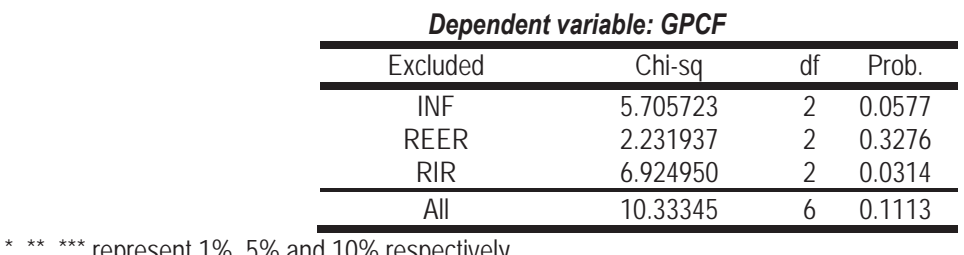

The results of exogeneity test indicate that not all variables can be treated as endogenous. The variables can be treated as endogenous individually but not always jointly. The pairwise Granger causality shows that there is unidirectional causation from interest rates to private capital formation and from inflation to PCF.

\subsection{Stationarity Analysis}

A stochastic process, correspondingly a time series, is stationary if the means and variances of such series are constant overtime and the covariances between the two time periods " $\mathrm{t}$ " and " $\mathrm{t}+\mathrm{k}$ ", depend only on the distance (lag) $\mathrm{k}$ between these two time periods and not on the actual time period " $\mathrm{t}$ " at which these covariances are considered (Katoset al., 2000). Technically, non-stationarity implies that the moments (mean, variance and other higher moments) of the distribution from which the series of observations were generated/drawn is not constant/ time invariant, depending rather on the point in time at which the observations were made (Harvey, 1990).

Various solutions are proposed to deal with non-stationary time series, these include differencing of the series to reach stationarity or combining different sets of time series together at level form provided they are cointegrated ${ }^{2}$. Preferably, any non-stationary series should be preceded by identifying the order of integration of each series by running the stationarity tests to decide the number of times a series should be differenced to achieve stationarity. A series that is to be differenced $d$ times to achieve stationarity is said to be integrated of order $d$, thus $\sim$ (d). In literature, several tests have been proposed to tests for stationarity of time series data, however this study employs the modified DF test (DFGLS) as well as the Ng-Perron test due to their superiority over the standard Dickey-Fuller (DF, ADF)and the PhillipsPerron (PP) tests.In empirical research, regressing of one non-stationary series on the other may lead to spurious regression, which adversely affects the validity of the standard statistical tests (t and F-tests). Various solutions are proposed to deal with non-stationary time series; these include differencing of the series to reach stationarity. The most notable tests include the ADF proposed by Dickey and Fuller (1979) as well as the PP by Phillips andPerron (1988), which were found to lack power and hence a development of other tests.

\subsubsection{The DF-Generalized Least Squares (DF-GLS) test}

This detrending test was suggested by Elliott, Rothenberg \& Stock in $1996^{3}$. These authors optimized the power of the

${ }^{2}$ Formally, time series $X t$ and Ytare said to be cointegrated of order $(d, b$,$) that is Y t \sim C l(d, b)$, where $d \geq b \geq 0$, if both series are I (d) and there exists a linear combination of the series such that $\left[\beta_{1} x_{t}+\beta_{2} y_{t}\right]$ is $I(d, b)$ and the vector $\beta_{1} x_{t}+\beta_{2} y_{t}$ is called the cointegrating vector. For the case of $n$ series where $n>2$, an $n \times 1$ vector $\beta$ exist such that $x_{t}^{\prime} \beta \sim 1(d-b)$ where $x t$ denotes an $n \times 1$ vector of series $x 1 t$, $x 2 t$, .......xnt, (Engle and Granger, 1987, p253; Charemza and Deadman, 1997, p.125).

${ }^{3}$ See details of the test in G. Elliott, T.J.Rothenberg, and J.H.Stock, "Efficient Tests for an Autoregressive Unit Root," Econometrica, Vol.64, 1996,pp813-836. 
ADF test by detrending. The test is based on testing the null hypothesis that $\phi_{0}=0$ given the following regression:

$$
\Delta Z_{\mathrm{t}}^{\mathrm{d}}=\varphi_{0} \mathrm{Z}_{\mathrm{t}}^{\mathrm{d}}+\varphi_{1} \Delta \mathrm{Z}_{\mathrm{t}-1}^{\mathrm{d}}+\ldots \ldots \ldots \ldots \ldots \ldots+\cdots+\varphi_{\mathrm{p}} \mathrm{Z}_{\mathrm{t}-\mathrm{p}}^{\mathrm{d}}+\varepsilon
$$

where $Z_{t}^{d}$ is the de-trended series $Z_{\mathrm{t}}$. The null hypothesis of the test is that $Z_{t}^{d}$ has a random walk trend, possibly with a drift as follows:

$$
\mathbf{Z}_{\mathbf{t}}^{\mathbf{d}}=\mathbf{Z}_{\mathbf{t}}-\hat{\boldsymbol{\delta}}_{\mathbf{0}}-\hat{\boldsymbol{\delta}}_{\mathbf{1}} \mathbf{t}
$$

Two possible alternative hypotheses accrue to this test:

(a) $Z_{t}$ is stationary about a linear trend

(b) $Z_{t}$ is stationary with a non-zero mean, but with no linear time trend.

Under the first alternative hypothesis, the DFGLS test is performed by first estimating the intercept and the trend using the generalized least squares technique. This estimation is performed by generating the following variables:

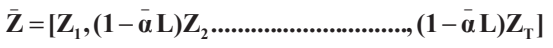

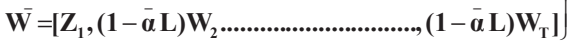

$$
\begin{aligned}
& \text { And } \mathrm{W}_{\mathrm{t}}=(1, \mathrm{t}) \bar{\alpha}=1+\frac{\bar{C}^{-}}{T}
\end{aligned}
$$

where $T$ represents the number of observations for $Z_{t}$ and $\bar{C}$ is fixed at $-13.7^{\mathrm{a}}$. Then an OLS regression is performed on the following equation: $\mathbf{Z}=\boldsymbol{\delta}_{0} \mathbf{W}+\overline{\boldsymbol{\delta}}_{1} \mathbf{W}_{\mathrm{t}}+\boldsymbol{\varepsilon}_{\mathrm{t}}$

and the OLS estimators $\hat{\delta}_{0}$ and $\hat{\delta}_{1}$ are then used to remove the trend from $\mathbf{Z}_{\mathrm{t}}$ above. Finally, the ADF is performed on the transformed variable by fitting the OLS regression given by equation (11) below:

$$
\Delta Z_{t}^{d}=\varphi_{0}+\rho Z_{t-1}^{d}+\sum_{j=1}^{k} \beta_{j} \Delta Z_{t-j}^{d}+\mu_{t}
$$

From equation (9), the null hypothesis that $\rho=0$ is tested using the tabulated critical values provided by Elliot et al (1996). Under the second alternative hypothesis, the DFGLS test is implemented as before but this time $\bar{C}$ is fixed at -7 in the equation of $\bar{\alpha}$, above. Then $\mathbf{Z}_{\mathbf{t}}^{\mathrm{d}}=\mathbf{Z}_{\mathbf{t}}-\hat{\boldsymbol{\delta}}_{\mathbf{0}}$ is computed and the ADF is fitted on the newly transformed variable and the null hypothesis of $\rho=0$ is evaluated using the tabulated critical values. The results pertaining to the most parameterized model are presented in Table 2 below.

\subsubsection{Ng-Perron unit root test}

$\mathrm{Ng}$ and Perron (2001) show that DGGLS exhibits size distortions and hence propose a test for unit root that has good size and power properties. These tests have similar size and power properties and simulations show that they perform better than the DF-GLS test (Ng and Perron 2001). $\mathrm{Ng}$ and Perron also address the problem of sensitivity of unit root testing to the choice of lag length. They propose the new information criteria, the Modified Information Criteria (MIC). The distinction between the standard information criteria such as the Akaike and the Schwartz Bayesian is that the former takes into account the fact that the bias in the sum of the autoregressive coefficients is highly dependent on the number of lags.

Table 2: Unit Root Test Results

\begin{tabular}{ccccc}
\hline Name & DF-GLS & $M Z_{\alpha}^{G L S}$ & $M Z_{t}^{G L S}$ & Inference \\
\hline GPCF & -0.8309 & -0.3459 & -0.2241 & $\mathrm{I}(1)$ \\
REER & -1.3273 & -4.9398 & -1.4906 & $\mathrm{I}(1)$ \\
RIR & $-3.0437^{*}$ & $-11.9453^{\star *}$ & $-2.4434^{* *}$ & $\mathrm{I}(0)$ \\
INF & -1.4917 & -4.4565 & -1.3811 & $\mathrm{I}(1)$ \\
\hline
\end{tabular}

Note: the Ng-Perron critical values for MZa\&MZt at $1 \%, 5 \%$ \& $10 \%$ are $[-13.8000,-8.1000,-5.7000 ;-2.5800,-1.1980$, 1.6200 respectively]. ${ }^{*},{ }^{* *},{ }^{* * *}$ represent level of rejection at $1 \%, 5 \%$ and $10 \%$ respectively 
The unit root test results show that GPCF, INF and REER are integrated of order one, while RIR is integrated of order zero. From an application of $\mathrm{Ng}$-Perron test show that the unit root hypothesis is rejected at 5 percent level of significance in the case of RIR. Therefore, $\mathrm{Ng}$-Perron test also confirms that variables is I(0).

\subsubsection{Cointegration Analysis: Bounds Test}

The bounds test approach requires that we perform the coefficient diagnostic test in order to find if the estimated coefficients are statistically equal to zero using the Wald test. The results of the Wald test are presented in table 5 below.

Table 3 : Wald test Results

\begin{tabular}{cccc}
\hline Test Statistic & Value & df & Probability \\
\hline F-statistic & 4.288147 & $(2,21)$ & 0.0274 \\
Chi-square & 8.576294 & 2 & 0.0137 \\
\hline
\end{tabular}

The wald test in table 5 above indicates that the explanatory variables are statistically significant. The F-statistic on the other hand appears to be greater than the upper bound (4.06)against the lower bound 3.03 at $k=3$, suggesting the presence of long-run relationship amongst the variables in question. This shows that gross private capital formation and interest rates drift together and thus may drift apart should there be a monetary policy shock. The establishment of the long-run amongst the variables compelled us to perform the vector error correction (VECM), which is represented by equation below:

$$
\triangle G P C F_{t}=\beta_{1}+\sum_{i=0}^{n} \beta_{2} \Delta R I R_{t-i}+\sum_{i=0}^{n} \beta_{3} \Delta N F_{t-i}+\sum_{i=0}^{n} \beta_{4} R E E R_{t-i}+\sum_{i=1}^{n} \beta_{5} \Delta G P C F_{t-i}+\beta_{8} E C_{t-1}+\pi_{t}
$$

Where the respective variables are of the same order of integration but those with order zero will cointegrate with high power, while those integrated with order one will cointegrate with low power. The value of $n$ is chosen using the AIC and the SIC. EC is the error correction component and $\pi$ is the random error term. The error correction term $(E C)$ is the lagged values of the error term that has been derived from the regression model. The results are presented in table 6 below.

Table 4: VECM Results

\begin{tabular}{ccccc}
\hline Error Correction: & $D(G P C F)$ & $D(I N F)$ & $D(R E E R)$ & $D(R I R)$ \\
\hline CointEq1 & -0.005178 & -0.026261 & 1.075069 & -0.223985 \\
& $(0.04216)$ & $(0.06099)$ & $(0.25388)$ & $(0.11052)$ \\
& {$[-0.12284]$} & {$[-0.43056]$} & {$[4.23463]$} & {$[-2.02659]$} \\
\hline
\end{tabular}

The VECM results reveal that about 0.5 percent of the disequilibrium is corrected each year by changes in gross private capital formation in South Africa. This is justified by the coefficient -0.005178 . This coefficient bears the expected sign (negative) as expected, because the negativity implies that the model is stable. Gross private capital formation responds slowly when there is a shock. In addition to the VECM, the impulse response functions (shown in appendix A) also justify the negative relationship between real rate of interest and private capital formation.

\section{Conclusions}

Although, the role of Private Capital Formation (PCF) in engineering growth and development is highly appreciated, PCF is inclined to changes in Government Policy (GP). This study set out to empirically investigate the impact of monetary policy on private capital formation in South Africa, following the IMF-World Bank policy recommendation that for her to achieve favourable growth rate and reduce poverty, she must develop the private sector and use it an engine of growth while also pursuing stringent fiscal policy and prudential monetary policy.

The results from this study indicated the impact of interest rates on PCF in the long-run is negative. This supports the Investment-Interest rates nexus in South Africa and therefore discerned that indeed, in the long-run, the costs of funds do matter to private investors when making decisions regarding expansion in fixed assets. Several principal 
conclusions therefore, emerge from this study. First, interest rates have implications on long-run private capital accumulation in South Africa, which might or might not be the case for other countries participating in the Southern African Development Community (SADC). The cost of capital has a bearing on long-run private capital accumulation in South Africa. Therefore, on aggregate basis, those countries experiencing low levels of bank lending rates and unrationed credit, ceteries' paribus, are likely to accumulate more capital and grow faster than those experiencing high levels of interest rates. The falling trends in private investment in South Africa (see figure 1) is a clear indication that, although SADC has served South Africa well in terms of low inflation and conduct of monetary policy, the country might be beginning to suffocate as its dominant partners prosper.

\section{References}

Ahmed, H. and Miller, M. (2000). Crowding-out and Crowding-in Effects of the Components of Government Expenditure, $A$ contemporary Economic Policy, Vol.18 (January): 124-33.

Akkina, K. and Mehmet, A. (2000). Determinants of Private Fixed Investment and the Relationship between Public and Private Capital Accumulation in Turkey. Pakistan Development Review, 41: 243-54.

Badawi, A. (2003). Testing Stationarity in Selected Macroeconomic Series from Sudan. (Unpublished) University of Manchester, Manchester.

Badawi, A. (2003). Private Capital Formation and Public Investment in Sudan: Testing the Substitutability and Complimentarity Hypothesis in a Growth Framework. Journal of International Development, 5 (June): 783-799.

Badawi, A. (2005). Private Capital Formation and Macroeconomic Policies in Sudan: An Application of Simple Autoregressive Model.

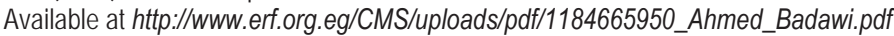

Barro, R.J. (1997). Determinants of economic growth: a cross-country empirical study, MIT Press :Cambridge, Mass, London.

Belloc, M. and Pietro, V. (2004), "How does Public Investment Affect Economic Growth in HIPC? An Empirical Assessment", Working PaperNo. 416, University of Siena.

Charemza, W. and Deadman, D. (1997). New Directions in Econometrics Practice: General to Specific Modeling, Cointegration and Vector Autoregression, (2nd Ed.), Edward Elgar Publishing, Cheltenham.

Charemza, W. (1990). Large Econometric Models of an East European Economy: A Critique of the Methodology. Economic Modeling, 8: 45-61.

Cornia, G.A. (1991). Is Adjustment Conducive to Long-term Development? The Case of Africa in the 1980s. InnocentiOccational Papers, Economic Policy Issues, No.21. Florence: Spedaledeglilnnocenti.

Demetriades, P. and Mamuneas, T. P. (2000). International Output and Employment Effects of Public Infrastructure Capital: Evidence from OECD Economies. Economic Journal, 110: 687-712.

Dhumale, R. (2000). Public Investment in the Middle East and North Africa: Towards Fiscal Efficiency. Development Policy Review, 18: 307-24.

Dickey, D. and Fuller, W. (1979). Distribution of estimators for Autoregressive Time Series and Units Roots, Journal of American Statistical Association, 74(366): 427-431.

Easterly, W. and Rabelo, S. (1993). Fiscal Policy and Economic Growth. Journal of Monetary Economics, 32 : 417-58.

Elliot, G.R, Rothenberg, T.J. and Stock, J.H. (1996). Efficient Tests for an Autoregressive Unit Root. Econometrica, 64: 813-36.

Engle, R. and Granger, C. (1987). Cointegration and Error Correction; Representation, Estimation and Testing. Econometrica, 55 (2), 1987: 251-78

Erenburg, S.J. and Wohar, M.E. (1995). Private and Public Investment: Are there Causal Linkages? Journal of Macroeconomics, 17: 130.

Everhart, S.S. and Sumlinski, M.A. (2001), "The Impact on Private Investment of Corruption and the Quality of Public Investment", Discussion Paper No.44, International Finance Corperation.

Fry, M.J. (1980). Savings, Investments, Growth, and the Cost of Financial Repression. World Development, 8: 317-327.

Fry, M.J. (1988). Money, Interest and Banking in Economic Development, John Hopkins University Press, Baltimore.

Galbis, V. (1979). Money, Investment and Growth in Latin America, 1961-1973. Economic Development and Cultural Change, 27: 42343.

Ghali, K.A. (1998). Public Investment and Private Capital Formation in Vector Error Correction Model for Growth. Applied Economics, 30 (June): 837-44.

Granger, C.W. and Newbold, P. (1974). Spurious Regression in Econometrics. Journal of Econometrics, 35: 143-159.

Granger, C.W. and Newbold, P. (1986). Forecasting Economic Time Series, (2nd Ed.) Academic Press, Inc., Orlando, Florida.

Harvey, A. (1990). Econometric Analysis of Time Series, (2nd Ed.), Phillip Allan, London.

Ibrahim, M. (2001). The Effects of Government Spending on Private Capital Formation: The Case of Malaysia. Journal of International Economics, 54: 187-201.

Johansen, S. (1988). Statistical Analysis of Cointegration Vectors. Journal of Economic Dynamics and Control, 12: 231-54.

Johansen, S. and Juselius, K. (1990). Maximum Likelihood Estimation and Inference on Cointegration with Application to the Demand for Money. Oxford Bulletin of Economics and Statistics, 52: 169-210.

Johnson, H. (1967). Essays in Monetary economics. Cambridge, Harvard University Press. 
Katos, V., Lawler, K. and Seddighi, H. (2000). Econometrics: A Practical Approach. London EC4P 4EE: Routledge.

Keynes, J.M. (1936). The General Theory of Employment, Interest and Money. New York: Harcourt, Brace and Company.

Kumar, M. and Mlambo, K. (1995). Determinants of Private Investment in Sub-Saharan Africa: An Empirical Analysis. A paper Presented at the 11th World Congress of the International Economic Association, Tunis, December: 22-24.

Laopodis, N. (2001). Effects of Government Spending on Private Investemnt. Applied Economics, 33 : 1565-1577.

Ligthart, J.E. (2000). Private Capital and Output Growth in Portugal: An Empirical Analysis. Working Paper, No.00/11, International Monetary Fund.

Matin, K.M. and Wasow, B. (1992). Adjustment and Private Investment in Kenya, World Bank Policy Research Working Paper, WPS 878, March. The World Bank.

McKinnon, R.I. (1973). Money and Capital in Economic Development, Washington D.C: Brookings Institution.

Mittnik, S. and Neumann, T. (2001). Dynamic Effects of Public Investment: Vector Autoregressive Evidence for Six Industrialized Countries. Empirical Economics, 26 (June): 429-36.

Narayan, P.K. (2004). Do Public Investments Crowd- Out Private Investments? Fresh Evidence from Fiij. Journal of Policy Modeling, 26:747-53.

$\mathrm{Ng}$, S.andPerron, P. (2001). Lag Length Selection and the Construction of Unit Root Tests with Good Size and Power. Econometrica, 69: $1519-1554$.

Ogunbenro, I.O., Alawode, A.A., and Mutabuka, P.C. (1996). The Effects of a Liberalized Financial System on Savings, Investment, and Growth in Nigeria: 1983-1996. African Journal of Economic Policy, June: 27-40.

Oshikoya, T. (1992). Interest rates Liberalization, Investment and Growth: The Case for Kenya. Savings and Development, African Development Bank, 16(3): 305-320.

Pereira, A.M. (2000). Is all capital Created Equal? Review of Economics and Statistics, 82 : 513-18.

Perron, P. (1989). The Great Crash, the Oil Price Shock, and the Unit Root Hypothesis. Econometrica, 57 (6): 1361-1401.

Perron, P. (1990). Testing for Unit Root in a Time Series with a Changing Mean. Journal of Business and Economic Statistics, 8(2): 153162.

Pesaran, M.H. and Pesaran, B. (1997).Working with Microfit 4.0: Interactive Econometric Analysis, Oxford University Press, Oxford.

Ramirez, M.D. (2001).The Impact of Public Investment on Private Investment Spending in Latin America: 1980-95. Atlantic Economic Journal, $28: 210-215$.

Rossiter, R. (2002). Structural Cointegration Analysis of Private and Public Investment. International Journal of Business and Economics, 1(1): 59-67.

Shafik, N. (1992). Modeling Private Investment in Egypt. Journal of Development Economics. 39: 263-277.

Shaw, S. (1973), Financial Deepening in Economic Development, New York: Oxford University Press.

Tobin, J. (1965). Money and economic growth. Econometrica, 33, 671-84. 